\title{
Determinants of scale of farm operation in the eastern region of Ghana
}

\author{
Nana Afranaa Kwapong ${ }^{1}$, Daniel Adu Ankrah ${ }^{1 *}$ D , Jonathan Nicholas Anaglo ${ }^{1}$ and Enoch Yao Vukey ${ }^{2}$
}

\begin{abstract}
Background: Ghana's smallholder share area under cultivation is witnessing a gradual decline, relative to the share of farmland under medium scale that is growing rapidly. Little attention has, however, been given to examining the drivers that influence scale of operation.

Method: Using survey data from 231 farmers, this study employed the binary probit regression to assess factors that influence scale of farm operation among cassava and maize farmers in Ghana's Eastern Region.

Results: The findings showed that factors that were significant and positively related to farm size were age, secondary education, land acquisition for maize farmers, and tertiary education for cassava farmers. On the other hand, factors that were significant and negatively related to farm size were gender, marital status, access to extension services for cassava farmers, and household size, membership of farmer-based organization and access to credit for maize farmers.
\end{abstract}

Conclusion: The study recommends the provision of mechanization support for medium-scale farmers coupled with the improvement of extension service delivery to medium-scale farmers. With messages focused on the adoption of improved technologies and mechanization of farm operations.

Keywords: Small-scale, Medium-scale, Farm size, Cassava, Maize, Ghana

\section{Background}

The consensus in both the extant literature and the development arena on the need to upscale farm sizes in Africa as a means to achieving the Sustainable Development Goal (SDG) - 2 of zero hunger is not in doubt. Jayne et al. [19] and [33] argued that the achievement of this realization requires a shift from small-scale farming to large-scale commercialized farming. The debate has interrogated the pathway for Africa's agricultural transformation. A pertinent research question that ensues include, whether Africa's agricultural transformation agenda should be pursued through dedicated attention

\footnotetext{
*Correspondence: dankrah@ug.edu.gh

${ }^{1}$ Department of Agricultural Extension, School of Agriculture, College

of Basic and Applied Sciences (CBAS), University of Ghana, P. O. Box LG 68, Legon, Ghana

Full list of author information is available at the end of the article
}

to large-scale commercial farming or otherwise? Much of these arguments and research questions are premised on the merit of efficient production systems and economies of scale.

Several studies indicate an inverse relationship between farm size and land productivity. These studies conclude against conventional wisdom that smaller farms rather generate higher productivity gains than larger farms (see $[21,23,51]$ for reviews of this literature). A plausible reason is that smallholder farms have lower labour transaction costs, more inputs-intensive, and specialized skills and knowledge [12, 21, 39]. Fan et al. [23] cautioned classifying small-scale farms as a homogenous group, shedding light that differential variations exist among small-scale farms. This implies that some smallscale farms are more profit-efficient than others. Perhaps, these small-scale farmers that are less profit-efficient 
should be supported to divert to seek non-farm employment opportunities.

Other researchers have suggested this to be counterproductive as this path will rather escalate poverty, food insecurity and social tensions. Attention could be turned to investing in commercializing smallholder agriculture [30, 35, 61]. Anang et al. [4] observed that farm size has a significantly positive effect on scale efficiency with most of the farms operating at increasing returns to scale. The argument requires a radical shift from small against large farm sizes to context-specific interventions targeting different types of farm sizes. This is because there is dynamism in the concept of farm size contingent on changes in a country's economic performance at the macro and micro-levels [22].

A debate that has gained less traction, is the growing numbers of home-grown medium-scale and large-scale farmers in Africa [5, 46, 47]. Jayne et al. [33] assessed transitioning in farm size distribution in Africa and found a decrease in land size holdings less than five hectares (small-scale farms), whereas there is a rapid increase in medium-scale (5 ha-100ha). This rapid increase is a result of three types of farmer groups. The first group is the influential rural elites who are in the rural areas and have acquired large farmlands, which is a departure from the usual case where most rural people have less than two hectares of land. The second group is the elite-urban based who are in the urban areas and have acquired farmland from non-farm income and the third group are the small-scale farmers who have transitioned to medium-scale sizes over years of farming, referred to by Jayne et al. [33] as "successful medium-scale farmers". The authors projected medium-scale farmers to control a share of farmland of about 20\% in Kenya, 32\% in Ghana, $39 \%$ in Tanzania, and over $50 \%$ in Zambia. The mediumscale farmers are predominantly middle-aged men formerly or currently employed by the public sector, having acquired large tracks of land purposively for agriculture $[5,34]$.

In Ghana, farm expansion to medium and large-scale has mostly been due to farm expansion from small farm sizes of two hectares or less and the entry of few urban elites who acquired farmland for commercial agricultural production $[14,17,34]$. This transitioning process appears peripheral with little recognition given to the dynamic features in the process of growth. The scanty studies that have reported the emergence of these medium and large-scale farmers in Ghana have shown positive spill-over effects to other small-scale farmers. For instance, Houssou et al. [30] reported on small-scale farmers gaining access to tractors from medium and large-scale farmers thereby being able to plough large sizes of farmlands for farming than they would have through rudimentary means. These medium and largescale farmers have transitioned surviving the challenges of farming. They have persevered, learnt from their mistakes, and made profits from their farming activities. These farmers have been able to increase market access, infrastructure, hired labour, weedicides, machinery, financial capital, improved/hybrid seeds, fertilizers, pesticides, veterinary drugs and agricultural extension services. They have overcome or adapted their farming strategies to survive the challenges of climate change, price shocks and limited financing options.

Generally, the literature on drivers of farm scale that focuses on Africa is scarce and disperse. For instance, Masters et al. [43] showed that demographic transitioning affects farm size upscaling in Africa and Asia that often leads to less land and a shift of labour into the nonfarm sector. Debonne, van Vliet, Ramkat, Snelder, and Verburg [18] argued that there is no difference in yield between small-scale farms and medium-scale farms in Kenya. Their study underscored the need to focus on medium-scale farms. Masters (2013) concluded that a rise in large-scale farms is a factor that reduces smallscale farms. Akudugu [10] concluded that an interaction between credit source and farm size significantly affects agricultural productivity in Ghana. Jayne et al. [33] showed a decline in small-scale farms in Africa and an inclination towards medium-scale farms, about $32 \%$ in Ghana. These authors also concluded a general rise to medium-scale farms in Ghana and additionally cautioned on the potential of medium-scale farms to exacerbate land scarcity and transition small-scale farms.

Maize and cassava constitute major staples in Ghana, ironically, few studies [41] on Ghana remain explicit in examining the drivers that underline the scale of operation of maize and cassava in Ghana. Khandker and Faruqee [37] argued that participation in the formal financial sector contributes to the transition to largescale farms. The debates appear inconclusive. This article aims to examine the determining factors that influence farm size among maize and cassava farmers in the Eastern Region of Ghana. An understanding of the factors influencing the scale of operation will inform policy decisions in promoting farming as a business among smallscale farmers, provide a better understanding of the features of medium-scale to design appropriate support systems for these farmers.

This paper contributes to bridging gaps in the literature in two ways. First, the article presents an understanding of factors that influence the scale of farm operation in the global south using the Eastern Region of Ghana as a case study. Indeed, this is a build-up to giving clarity to factors affecting the scale of operation. 
Second, few papers focus on factors affecting the scale of operation of major staples in Ghana. The few that exist in Ghana are rather skewed towards northern Ghana [4, 10, 49]. This paper, therefore, contributes to the limited papers [10] [53] on southern Ghana to reduce the unbalanced literature on Ghana.

\section{Method}

\section{Study area}

The study was undertaken in the Eastern Region of Ghana. Farmers interviewed were selected from three districts-Afram Plains South, Suhum Kraboa Coaltar and West Akim districts (Fig. 1). The Eastern Region of Ghana is a top producer of cassava with an average annual production of 4,466,906.01 Mt, and the second top producer of maize with an average production of 400,704.25 Mt. (MoFA, 2015). Both maize and cassava are major staples in Ghana mostly cultivated by smallholder farmers.

\section{Research design and sampling procedure}

The study used an ex post facto research design [16] to explain factors influencing farmer's scale of operation. According to Cohen et al. [16], ex post facto experiments begin with groups that are already different in some respect and search in retrospect for factors that brought about these differences [16]. Emphasis was laid on factors that influence scale of operation of cassava and maize farmers.

Farm size varies based on a specific strategy in production, degree of market integration, inputs access, innovation, infrastructure, and off-farm labour opportunities [27]. The land size threshold is used by many countries in categorizing farm sizes $[28,36]$. This approach considers the share of land effectively used by a farming household for farming [36]. We followed the land size categorization in the 2016/17 Ghana Living Standards Survey [25]. Small-scale farm sizes are categorized to have farm size areas less than 5 ha, mediumscale farm sizes have farm size areas between 55 and

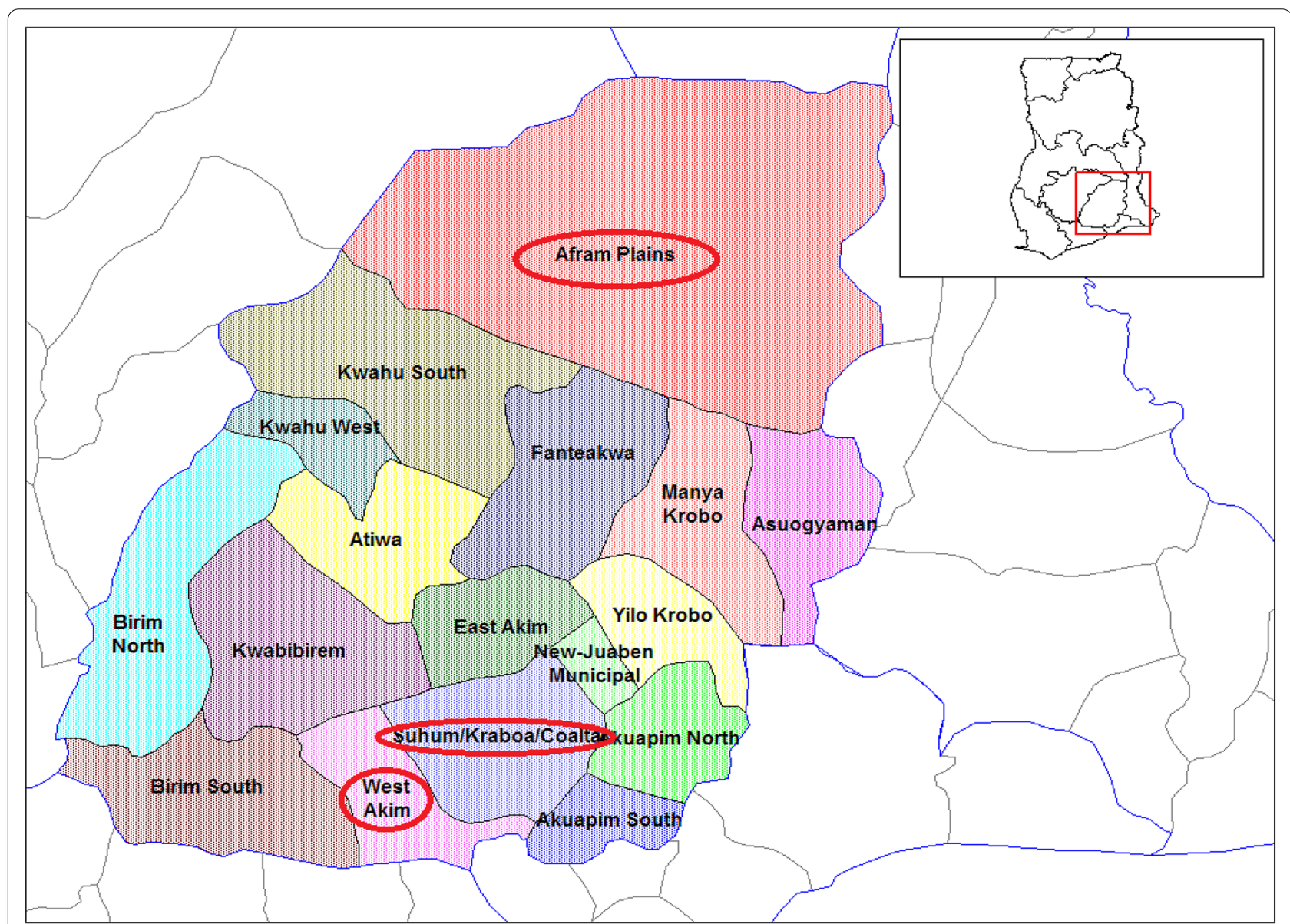

Fig. 1 Map of study area showing districts selected for the study. Source: https://en.wikipedia.org/wiki/Fanteakwa_District\#/media/File:Eastern_ Ghana_districts.png 
100 ha and large-scale farm size areas having farm size areas above 100 ha [25].

The land size approach has, however, been criticized for being overly simple, inadequate to characterize the specific problems faced by different typologies of farmers. The land size approach fails to account for the quality of resources, types of crops grown, or disparities across regions [36, 48, 52]. According to Khalil et al. [36], an option that could be considered is to define qualitative parameters of land, accounting for their potential, or their use. This would reduce the difficulties of comparing hectares in distinct contexts. For this study we focus on two different staple crops-maize and cassava-which makes comparison of hectares of the two crops difficult. To avoid comparing and treating hectares of maize same as cassava, we employed a qualitative approach to obtain qualitative parameters of land size categorization for the two crops.

We further organized focus group discussions where farmers were asked to categorize their scale of operation based on their own classification of small, medium and large-scale farm sizes. We observed differential classification of farm size among the cassava and maize farmers. Cassava farmers considered small-scale farmers to have farm sizes of less than two hectares, whereas maize farmers considered this group of farmers to have farm sizes less than five hectares. Medium-scale cassava farmers were categorized to have farm sizes of two to five hectares $(\mathrm{Ha})$ and five to twenty hectares for maize farmers. Large scale farm sizes were categorized as farm sizes above five hectares for cassava farmers and above 20 hectares for maize farmers. Farmers classification for small and medium-scale farm sizes falls in line with the classification in Ghana Living Standards Survey GLSS7 [25], however, farmer's classification of large-scale farm sizes is not consistent with the classification in GLSS7 [25]. This may be attributed to the fact that many of the farmers operate on a small scale.

Hence for this study, we use the following categorization of farm size (see Table 1). We categorized smallscale cassava farmers as farmers with farm sizes less than two hectares. Medium-scale cassava farmers for this study were categorized to have farm sizes above two hectares. The largest cassava farm size recorded for this study was 16 hectares which under the GLSS [25] farm size classification falls under the medium-scale farm size. For maize farmers, we categorized smallscale as farm sizes less than 5 hectares, and mediumscale as farm sizes above 5 hectares. The largest maize farm size included in this study was 80 ha which did not exceed 100 hectares.

The farmers were randomly selected from three districts in the Eastern Region: Afram Plains South, Suhum Kraboa Coaltar and West Akim districts. Additionally, three operational areas were randomly selected from the total number of operational areas in each of the selected districts. Farmer population lists from operational areas were obtained from the districts Department of Agriculture. Based on Arnab [6] formula of drawing without replacement, a total of 231 farmers were selected from the farmer population list (Table 1). This was done by using the lottery system where selection was done without replacement, hence the total farmer population always reduced by one. Using this method, every farmer in the population has the same probability of being selected [44]. The data were collected from March to September 2019.

We used a semi-structured questionnaire to gather information on farmer characteristics, economic activities, goals and aspirations, land acquisition, land ownership/control, land use, production practices, access to finance, farm planning, budgeting and records keeping. Farmers were also asked for their opinion on factors that had accounted for their current farm size operations.

\section{Analytical methods Model specification}

The objective of this paper was to examine the factors that affect the scale of operation or farm size among cassava and maize farmers in Ghana. Given that the decision to choose a farm size is a discrete outcome, the appropriate econometric procedure used is a choice model. Specifically, binary Logit and Probit models are the most appropriate in this case. Moreover, it is argued that binary probit and logit produce similar results [8]. This

Table 1 Farm size categorization for maize and cassava farmers

\begin{tabular}{|c|c|c|c|}
\hline \multicolumn{2}{|l|}{ Cassava farmers } & \multicolumn{2}{|l|}{ Maize farmers } \\
\hline & Frequency (\%) & & Frequency (\%) \\
\hline Landholding size $(\mathrm{Ha})$ & & Landholding size (ha) & \\
\hline Small-scale (less than $2 \mathrm{Ha}$ ) & $97(80.17)$ & Small-scale (less than 5 ha) & 85 ( 77.27$)$ \\
\hline Medium-scale (more than $2 \mathrm{ha}$ ) & $24(19.83)$ & Medium-scale (more than 5 ha) & $25(22.73)$ \\
\hline
\end{tabular}

Source: Field Data, 2019 
study employed the binary probit model. Basically, the theoretical layout of the probit model was specified as:

$$
S_{i}=Z^{h} \alpha+\varepsilon,
$$

where $S_{i}$ is a binary latent dependent variable denoting the decision of cultivating a farm size $(1$, if a farmer decides to cultivate medium-scale or 0 small-scale), $\mathrm{Z}^{h}$ is the explanatory variable of the regression related to the farmer, $\alpha$ is the parameter to be estimated, and $\varepsilon$ is the independent error term, identically distributed with zero mean and constant variance. The coefficient of a binary choice model does not have a direct interpretation. Therefore, the marginal effect (marginal propensity to save) must be computed by taking the first partial derivative of Eq. 3 concerning $\mathrm{Zh}$. The marginal effect shows the effect of a unit change in the explanatory variable, which brings about a change in the dependent variable [29]. The marginal effect was expressed as,

$$
\frac{\delta \operatorname{Pr}\left(S_{i}=1 / Z^{h}\right)}{\delta Z^{h}}=\frac{\delta E\left(\text { Size }_{i} / Z^{h}\right)}{\delta Z^{h}}=\Omega\left(Z^{h} \alpha\right) \alpha .
$$

The farmers' decision of cultivating a particular farm size can be written as:

$$
\begin{aligned}
& \operatorname{Pr}\left(\text { Size }_{i}=1\right)=\operatorname{Pr}\left(\text { Size }_{i}^{*}>0\right)=\operatorname{Pr}\left(\varepsilon_{i}>-\alpha Z^{h}\right) \\
& =1-\Phi\left(-\alpha Z^{h}\right)
\end{aligned}
$$

where $\Phi$ is the cumulative distribution function for $\varepsilon_{i}$. The explanatory variables extracted from the data are reorganized into socioeconomic characteristics, household assets and institutional variables related to the farmers.

\section{Results and discussion Descriptive results}

Out of 231 farmers who responded to the survey, 121 farmers cultivated cassava representing 52 percent. However, 111 farmers constituted 48 percent cultivated maize. Seventy-eight (78) percent of the farmers were involved in small-scale farming while the rest engaged in medium-scale farming. Eighty percent $(80 \%)$ of the respondents were engaged in cassava small-scale farming while $77 \%$ of maize farmers were engaged in smallscale farming (Table 2). This supported the claim that the agricultural sector in Ghana was largely dominated by small-scale farmers who cultivate less than a hectare of farmland [1]. Moreover, a report by the Food and Agricultural Organization (FAO) claimed that most farms in Ghana have an average size of less than 1.6 hectares [22]. This was so because the agricultural land tenure system is largely by inheritance. Therefore, most farmlands are fragmented among family members from one generation to another [20]. This justified why most farmlands were self-own and largely used for small-scale farming.

Almost all farmers were married and had an average household size of seven. Large family size is a predominant feature in rural areas in Ghana [25]. Farmers with large family sizes tend to depend on the family members for additional unpaid labour for farming activities $[23,38]$. There is limited extension access among cassava small-scale farmers (0.278) and medium-scale farmers (0.166). Kwapong, et al. [38] underscored the need for pluralistic extension (government sources, private and farmer-to-farmer) in bridging extension gaps in underserved communities. However, farmers who cultivate maize on a medium-scale, had high extension access (0.960) while small-scale maize farmers had limited extension access. This is because farmers who cultivated maize on a medium-scale were more likely to contact extension agents for improved seeds, fertilizers, and advisory services.

The majority of the farmers do not have access to credit facility. This was due to credit market imperfection in Ghana. Agricultural credit from donor partners has fallen dramatically in recent years because of the observed high risk [15, 54]. This is because rural farmers are high-risk debtors due to their penury status and the perception that they are repayment defaulters $[9$, 45]. This makes financial sector borrowing become a tough choice for most farmers even though it is widely documented that farmers' access to credit is an important factor in improving agricultural productivity $[7,25$, 56]. Most farmers, therefore, resort to informal credit sources such as money lenders, friends, relatives, traders, microcredit associations, etc.; Sekyi et al., [56] and Akudugu [10] found a significant relationship between farmers' access to informal credit, farm size and agricultural productivity.

\section{Determinants of farm size}

Probit estimates of determinates of the scale of operation among maize and cassava farmers in the Eastern Region of Ghana are presented in Table 3. Factors that were significant and positively related to farm size were age, secondary education, land acquisition for maize farmers, and tertiary education for cassava farmers.

On the other hand, factors that were significant and negatively related to farm size were gender, marital status, access to extension services for cassava farmers, and household size, membership of farmer-based organizations (FBOs) and access to credit for maize farmers. This implies that any increase in any of these variables would lead to a decrease in the farm size. 


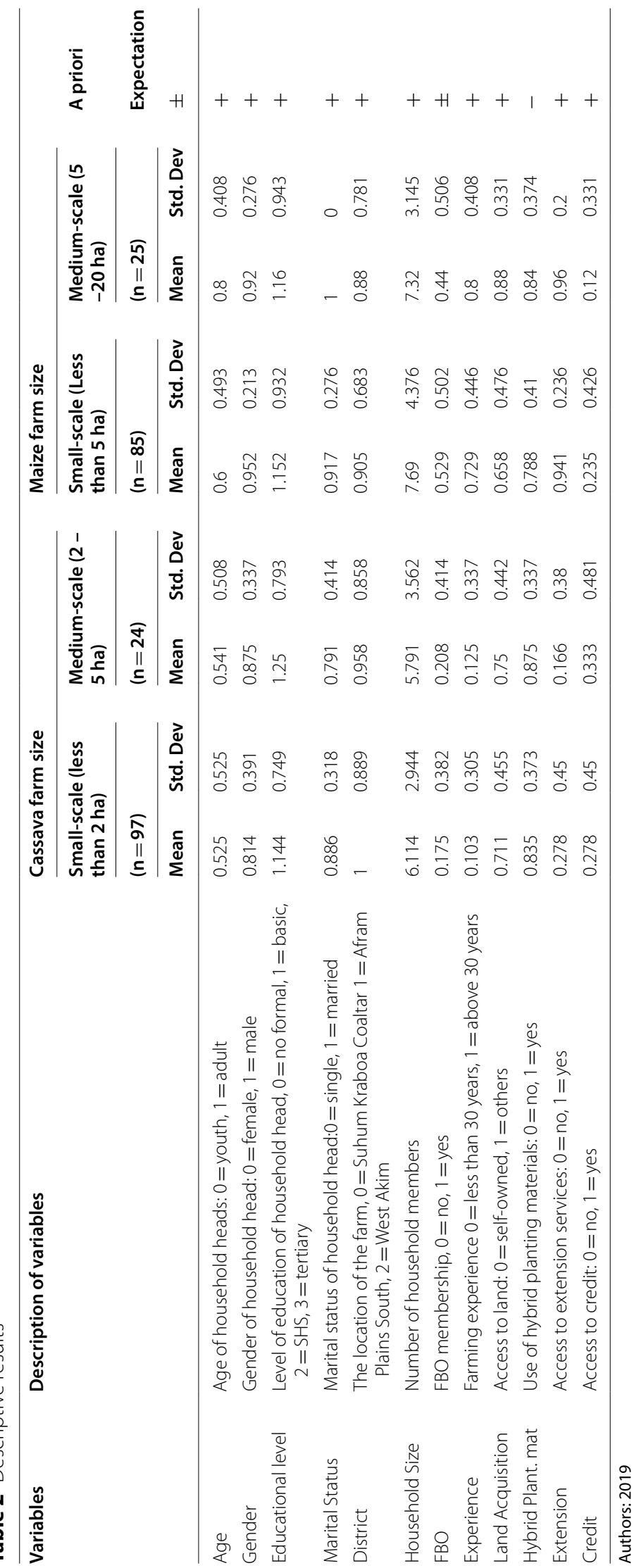


Table 3 Determinants of scale of operation for cassava and maize

\begin{tabular}{|c|c|c|c|c|c|c|c|c|}
\hline \multirow{3}{*}{$\begin{array}{l}\text { Variables } \\
\text { Demographic }\end{array}$} & \multicolumn{4}{|c|}{ Probit model } & \multicolumn{4}{|l|}{ Logit model } \\
\hline & \multicolumn{2}{|l|}{ Cassava (1) } & \multicolumn{2}{|l|}{ Maize (2) } & \multicolumn{2}{|l|}{ Cassava (1) } & \multicolumn{2}{|l|}{ Maize (2) } \\
\hline & Reg. coeff & Marginal effect & Reg. coeff & Marginal effect & Reg. coeff & Marginal effect & Reg. coeff & Marginal effect \\
\hline Age & $\begin{array}{l}0.202 \\
(-0.163)\end{array}$ & $\begin{array}{l}0.052 \\
(-0.042)\end{array}$ & $\begin{array}{l}0.810^{* * *} \\
(-0.195)\end{array}$ & $\begin{array}{l}0.193 \\
(-0.039)\end{array}$ & $\begin{array}{l}0.353 \\
(-0.285)\end{array}$ & $\begin{array}{l}0.052 \\
(-0.048)\end{array}$ & $\begin{array}{l}1.303^{* * *} \\
(-0.339)\end{array}$ & $\begin{array}{l}0.182 \\
(-0.046)\end{array}$ \\
\hline Gender & $\begin{array}{l}0.454^{* *} \\
(-0.218)\end{array}$ & $\begin{array}{l}0.104 \\
(-0.043)\end{array}$ & $\begin{array}{l}-0.446 \\
(-0.338)\end{array}$ & $\begin{array}{l}-0.129 \\
(-0.105)\end{array}$ & $\begin{array}{l}0.799^{* *} \\
(-0.4)\end{array}$ & $\begin{array}{l}0.102 \\
(-0.049)\end{array}$ & $\begin{array}{l}-0.769 \\
(-0.556)\end{array}$ & $\begin{array}{l}-0.133 \\
(-0.12)\end{array}$ \\
\hline \multicolumn{9}{|l|}{ Educational level } \\
\hline 1. Basic & $\begin{array}{l}0.276 \\
(-0.207)\end{array}$ & $\begin{array}{l}0.07 \\
(-0.049)\end{array}$ & $\begin{array}{l}0.0375 \\
(-0.198)\end{array}$ & $\begin{array}{l}0.009 \\
(-0.048)\end{array}$ & $\begin{array}{l}0.472 \\
(-0.381)\end{array}$ & $\begin{array}{l}0.067 \\
(-0.058)\end{array}$ & $\begin{array}{l}-0.007 \\
(-0.333)\end{array}$ & $\begin{array}{l}-0.001 \\
(-0.054)\end{array}$ \\
\hline 2. Secondary & $\begin{array}{l}-0.006 \\
(-0.236)\end{array}$ & $\begin{array}{l}-0.001 \\
(-0.052)\end{array}$ & $\begin{array}{l}0.499^{* *} \\
(-0.237)\end{array}$ & $\begin{array}{l}0.137 \\
(-0.064)\end{array}$ & $\begin{array}{l}-0.017 \\
(-0.429)\end{array}$ & $\begin{array}{l}-0.002 \\
(-0.061)\end{array}$ & $\begin{array}{l}0.795^{* *} \\
(-0.392)\end{array}$ & $\begin{array}{l}0.13 \\
(-0.073)\end{array}$ \\
\hline 3. Tertiary & $\begin{array}{l}0.808^{* *} \\
(-0.362)\end{array}$ & $\begin{array}{l}0.244 \\
(-0.12)\end{array}$ & $\begin{array}{l}0.338 \\
(-0.304)\end{array}$ & $\begin{array}{l}0.089 \\
(-0.082)\end{array}$ & $\begin{array}{l}1.375^{* *} \\
(-0.607)\end{array}$ & $\begin{array}{l}0.244 \\
(-0.137)\end{array}$ & $\begin{array}{l}0.474 \\
(-0.538)\end{array}$ & $\begin{array}{l}0.074 \\
(-0.1)\end{array}$ \\
\hline \multicolumn{9}{|l|}{ District } \\
\hline 1. Afram Plains South & $\begin{array}{l}0.342^{*} \\
(-0.18)\end{array}$ & $\begin{array}{l}0.0950 \\
(-0.051)\end{array}$ & $\begin{array}{l}-0.444^{* *} \\
(-0.176)\end{array}$ & $\begin{array}{l}-0.115 \\
(-0.046)\end{array}$ & $\begin{array}{l}0.551^{*} \\
(-0.311)\end{array}$ & $\begin{array}{l}0.089 \\
(-0.059)\end{array}$ & $\begin{array}{l}-0.760^{* *} \\
(-0.303)\end{array}$ & $\begin{array}{l}-0.116 \\
(-0.054)\end{array}$ \\
\hline 2. West Akim & $\begin{array}{l}0.004 \\
(-0.165)\end{array}$ & $\begin{array}{l}0.001 \\
(-0.040)\end{array}$ & $\begin{array}{l}0.061 \\
(-0.206)\end{array}$ & $\begin{array}{l}0.018 \\
(-0.061)\end{array}$ & $\begin{array}{l}-0.062 \\
(-0.29)\end{array}$ & $\begin{array}{l}-0.008 \\
(-0.046)\end{array}$ & $\begin{array}{l}0.077 \\
(-0.347)\end{array}$ & $\begin{array}{l}0.013 \\
(-0.07)\end{array}$ \\
\hline Marital status & $\begin{array}{l}-0.562^{* * *} \\
(-0.205)\end{array}$ & $\begin{array}{l}-0.170 \\
(-0.068)\end{array}$ & - & - & $\begin{array}{l}-0.969^{* * *} \\
(-0.344)\end{array}$ & $\begin{array}{l}0.046 \\
(-0.079)\end{array}$ & - & - \\
\hline Household size & $\begin{array}{l}-0.000 \\
(-0.026)\end{array}$ & $\begin{array}{l}-0.000 \\
-(0.007)\end{array}$ & $\begin{array}{l}-0.064^{* *} \\
(-0.026)\end{array}$ & $\begin{array}{l}-0.017 \\
(-0.007)\end{array}$ & $\begin{array}{l}0 \\
(-0.043)\end{array}$ & $\begin{array}{l}0 \\
(-0.007)\end{array}$ & $\begin{array}{l}-0.103^{* *} \\
(-0.045)\end{array}$ & $\begin{array}{l}-0.015 \\
(-0.008)\end{array}$ \\
\hline Farming experience & $\begin{array}{l}-0.031 \\
(-0.237)\end{array}$ & $\begin{array}{l}-0.008 \\
(-0.060)\end{array}$ & $\begin{array}{l}-0.052 \\
(-0.198)\end{array}$ & $\begin{array}{l}-0.014 \\
(-0.053)\end{array}$ & $\begin{array}{l}-0.007 \\
(-0.398)\end{array}$ & $\begin{array}{l}-0.001 \\
(-0.068)\end{array}$ & $\begin{array}{l}-0.065 \\
(-0.345)\end{array}$ & $\begin{array}{l}-0.01 \\
(-0.062)\end{array}$ \\
\hline Land acquisition & $\begin{array}{l}0.23 \\
(-0.166)\end{array}$ & $\begin{array}{l}0.0573 \\
(-0.039)\end{array}$ & $\begin{array}{l}0.938^{* * *} \\
(-0.204)\end{array}$ & $\begin{array}{l}0.216 \\
(-0.037)\end{array}$ & $\begin{array}{l}0.381 \\
(-0.293)\end{array}$ & $\begin{array}{l}0.054 \\
(-0.045)\end{array}$ & $\begin{array}{l}1.540^{* * *} \\
(-0.362)\end{array}$ & $\begin{array}{l}0.205 \\
(-0.043)\end{array}$ \\
\hline $\begin{array}{l}\text { Hybrid planting materi- } \\
\text { als }\end{array}$ & $\begin{array}{l}0.269 \\
(-0.205)\end{array}$ & $\begin{array}{l}0.065 \\
(-0.046)\end{array}$ & $\begin{array}{l}0.476^{* *} \\
(-0.218)\end{array}$ & $\begin{array}{l}0.115 \\
(-0.048)\end{array}$ & $\begin{array}{l}0.443 \\
(-0.36)\end{array}$ & $\begin{array}{l}0.06 \\
(-0.052)\end{array}$ & $\begin{array}{l}0.814^{* *} \\
(-0.374)\end{array}$ & $\begin{array}{l}0.116 \\
(-0.054)\end{array}$ \\
\hline Extension & $\begin{array}{l}-0.426^{* *} \\
(-0.177)\end{array}$ & $\begin{array}{l}-0.102 \\
(-0.038)\end{array}$ & $\begin{array}{l}-0.214 \\
(-0.345)\end{array}$ & $\begin{array}{l}-0.059 \\
-(0.099)\end{array}$ & $\begin{array}{l}-0.759^{* *} \\
(-0.319)\end{array}$ & $\begin{array}{l}-0.101 \\
(-0.043)\end{array}$ & $\begin{array}{l}-0.155 \\
(-0.641)\end{array}$ & $\begin{array}{l}-0.024 \\
(-0.12)\end{array}$ \\
\hline Credit & $\begin{array}{l}0.085 \\
(-0.148)\end{array}$ & $\begin{array}{l}0.022 \\
(-0.040)\end{array}$ & $\begin{array}{l}-0.521^{* *} \\
(-0.216)\end{array}$ & $\begin{array}{l}-0.124 \\
(-0.045)\end{array}$ & $\begin{array}{l}0.121 \\
(-0.259)\end{array}$ & $\begin{array}{l}0.018 \\
(-0.045)\end{array}$ & $\begin{array}{l}-0.859^{* *} \\
(-0.371)\end{array}$ & $\begin{array}{l}-0.119 \\
(-0.052)\end{array}$ \\
\hline Constant & $\begin{array}{l}-1.456^{* * *} \\
(-0.427)\end{array}$ & & $\begin{array}{l}-1.108^{*} \\
(-0.603)\end{array}$ & & $\begin{array}{l}-2.407^{* * *} \\
(-0.744)\end{array}$ & & $\begin{array}{l}-1.966^{*} \\
(-1.042)\end{array}$ & \\
\hline Observations & 120 & & 103 & & 120 & & 103 & \\
\hline LR Chi2(14) & 24.09 & & 52.05 & & 23.75 & & 50.35 & \\
\hline Prob $>$ Chi2 & 0.045 & & 0 & & 0.049 & & 0 & \\
\hline Pseudo-R2 & 0.067 & & 0.152 & & 0.065 & & 0.147 & \\
\hline
\end{tabular}

Asterisks denote significance levels: ${ }^{*}{ }^{* *}$ and ${ }^{* * *}$ shows significant at $P=0.10,0.05$ and 0.01

In the results in Table 3 above, we focus on the discussion of the probit results and additionally present the logit results as a robust/sensitivity check. The results revealed that there is a direct relationship between the age of maize farmers and the size of farmland for both probit and logit models. As farmers age increases there is a possibility that farmers would likely increase their unit of farmland for cultivating maize. Age has been associated with the size of farm operations [13]. Age is an indication of the level of experience of farmers, which can have direct implications for the decision-making processes and physical ability to manage particular enterprises [13]. According to Kwapong et al. [38], farmers are likely to increase their farm sizes over the years based on their experiences and the decision to reinvest their profits into their farming business. As farmers grow older and have reduced physical ability to engage in farm activities that require strength, they are likely to decide to hire labourers and mechanize their operations in expanding on their farm size. Even though age is correlated with experience, it is important to note that farmers make use of both direct and indirect experience in decision on farm size. Farmer's experience is gained by farming over the years and also indirectly by collecting information 
from other fellow farmers. Santeramo [54] found that both direct and indirect experience influences farm size. Experience directly acquired is relevant for medium and large farms [54]. Experience indirectly acquired through the spillover effect of seeing other farmers expand their farm size over the years is relevant for farmers with small farm sizes. Santeramo et al. [52] additionally showed that large farm size positively affects participation in agricultural insurance in Italy. This is contrary to a finding by Ankrah et al. [2] that showed that low knowledge about insurance products contributed to low agricultural access and acceptability in the case of Ghana. Giampietri et al. [15] additionally highlighted the role of trust in insurance uptake in Italy.

The findings (Table 3) also revealed that for cassava farmers, farmland size is likely to decrease by $10 \%$ when cultivated by female farmers. Cassava production is labour intensive and entails gender dynamics in many production activities including land clearing, tillage, planting, weeding, harvesting, and processing. About $80 \%$ of land preparation is done by men [40]. For cassava production, males are more technically efficient than their female counterparts in productive function [32]. As women age, they remain limited to engage in certain productive functions coupled with their differential access to productive resources [3]. Women for instance hire labour to perform most of the productive functions, which has a significant effect on their scale of operation. This result implies that, there is less prospect for increased scale of operation for sustainable cassava production among the female farmers.

The results (Table 3) also revealed that, cassava farmers with tertiary education have a probability of increasing their farmland by $24 \%$. Also, if maize farmers have some level of secondary school education, there is a probability of increasing their farmland by $14 \%$. Farmers' with some level of education higher than basic education were more likely to increase their scale of operation. This finding agrees with Jayne et al. [33], who observed an increase in the number of the elite in the urban and rural areas who have acquired farmlands from non-farm income. This finding, however, differs from that of Tolulope and Omonona [59] who found that as farmers acquire additional years of education, they tend to drift towards paid jobs which consequently reduces the amount of time available for farm activities and a decline in the area of land cultivated.

The study findings (Table 3) revealed that farmers who are married and cultivating cassava are likely to decrease their farmland size by $17 \%$. Married farmers may have a lot of family needs and more use for limited resources that can be invested in farm expansion, hence may decrease on their scale of operation. This result is consistent with Udensi et al. [60] who found a negative relationship between marital status, farm size and adoption of improved cassava varieties. All the maize farmers included in this study were married, hence there was no variation in their choices.

We also found (Table 3) an inverse relationship between the household size of maize farmers and the farm size under cultivation. If household size increases, farmland size under maize cultivation decreases. This can probably be explained by the land tenure system in Ghana. According to Donkor and Owusu [20], the agricultural land tenure system is largely by inheritance in Ghana. Therefore, most farmlands are divided equally into smaller pieces among family members from one generation to another [20]. This reduces the size of farmland under cultivation. Also, with larger household sizes, families use some of the resources to cater for children and other household needs. Hence, reducing the available resources that can be invested in expanding farm size.

Maize farmers who are members of farmer-based organizations (FBOs) are likely to decrease their farm size by two percent (Table 3 ). This can be explained by farmers focusing on intensification with increased demand for mechanization $[17,58]$. Also, the kind of agricultural information that maize farmers receive from extension agents is mainly centered on promoting diversification of farm operation and intensification to increase efficiency and productivity [38]. As such, maize farmers tend to focus on increasing productivity of their current scale of operation and making gradual expansion of their farm size.

The results further revealed that maize farmers who do not own their land were likely increase their farmland size for maize cultivation by $22 \%$. Land acquisition has a substantial influence on the scale of operation. Purchased farmlands, leased and those acquired through shared crop contracts are directly associated with farmers scale of operation. Farmers involved in shared cropping arrangements are likely to farm larger acreages as they must share the harvested produce with the landowner. Farmers renting farmlands, mostly plant produce on all the rented land and pay a fee to the landowner. Thus, the farmer rents the size of land for which he is prepared and capable of farming in the immediate term. Farmers who inherited land continuously expanded their farm size and rented or went into shared cropping arrangements with other farmers. Giampietri et al., [15] argued that trust was important aside land tenureship. This is because trust positively affects decision to insure crops.

The results also revealed that access to extension services had an inverse influence on farm size under cassava cultivation. Thus, if a farmer has access to extension services, he might decrease farmland under cassava 
cultivation by $10 \%$. This can be explained by the emphasis on extension messages that centered on encouraging the adoption of improved technologies, intensification, and diversification of farming activities to increase the efficiency and productivity of farmers.

The results also show that maize farmers with access to credit are likely to decrease their farmland by $12 \%$. This is explained by the fact that farmers may not likely invest the credit into their farm operation but may use the credit for other non-agricultural-related activities. Most of the farmers interviewed for this study relied on their own capital for their farming activities. Most farmers resort to informal credit sources such as money lenders, friends, relatives, traders, microcredit associations. Sekyi et al. [56] and Akudugu [10] found a significant relationship between farmers' access to informal credit, farm size, and agricultural productivity.

\section{Conclusion}

This study assessed factors that influence farm size/scale of operation among cassava and maize farmers in the Eastern region of Ghana. The findings showed that factors that were significant and positively related to farm size were age, secondary education, land acquisition for maize farmers, and tertiary education for cassava farmers. On the other hand, factors that were significant and negatively related to farm size were gender, marital status, access to extension services for cassava farmers, and household size, membership of farmer-based organizations (FBOs) and access to credit for maize farmers.

\section{Policy recommendations}

We recommend that government should provide mechanization support for medium-scale farmers. This is premised on the finding that as farmers age, they are likely to increase their farm size. However, as farmers grow older, they have reduced physical ability to engage in farm activities that require strength, they are likely to decide to hire labourers and mechanize their operation in expanding on their farm size. There is therefore the need to explore labour-saving technologies by mechanizing farm operations to reduce cost and demand for labour for medium-scale farmers.

We recommend improvement in the delivery of agricultural extension messages to medium-scale farmers focusing on the adoption of improved technologies and mechanization to increase farmers productivity.

\section{Limitations and assumptions}

Results of the study can be generalized only to the Eastern Region of Ghana involving maize and cassava farmers within the Afram Plains South, Suhum Kraboa Coaltar and West Akim districts. It was assumed that the survey results accurately portrayed surveyed farmers' perceptions of determinants that affect the scale of operation.

\section{Abbreviations}

SDG: Sustainable Development Goal; GLSS: Ghana Living Standards Survey; Ha: Hectares; FAO: Food and Agricultural Organization; FBOs: Farmer-based organizations.

\section{Acknowledgements}

We would like to acknowledge all participants who provided information for this study.

\section{Authors' contributions}

Conceptualization, methodology, writing original draft, reviewing and editing were done by all authors. All authors read and approved the final manuscript.

\section{Funding}

Not applicable.

Availability of data and materials

Data collected for the study can be made available upon request.

\section{Declarations}

Ethics approval and consent to participate

All respondents agreed to participate in the focus group discussions and the survey.

\section{Consent for publication}

All authors read and agreed to the published version of the manuscript.

Competing interests

Not applicable.

\section{Author details}

${ }^{1}$ Department of Agricultural Extension, School of Agriculture, College of Basic and Applied Sciences (CBAS), University of Ghana, P. O. Box LG 68, Legon, Ghana. ${ }^{2}$ Department of Agricultural Economics and Agribusiness, School of Agriculture, College of Basic and Applied Sciences (CBAS), University of Ghana, P. O. Box LG 68, Legon, Ghana.

Received: 29 September 2020 Accepted: 11 May 2021

Published online: 10 June 2021

\section{References}

1. Adams D. Determinants of microcredit access and farmers' investment in smallscale peri-urban agriculture: A case study of Dzorwulu vegetable farmers (Unpublished masters' thesis). Accra, Ghana: University of Ghana; 2015.

2. Ankrah DA, Kwapong NA, Eghan D, Adarkwah F, Gyambiby-Boateng D. Agricultural insurance access and acceptability-examining the case of smallholder farmers in Ghana. Agric Food Secur. 2021. https://doi.org/10. 1186/s40066-021-00292-y.

3. Ankrah DA, Freeman CY, Afful A. Gendered access to productive resources-evidence from smallholder farmers in Awutu Senya West District of Ghana. Sci Afr. 2020. https://doi.org/10.1016/j.sciaf.2020.e00604.

4. Anang BT, Bäckman B, Rezitis A. Does farm size matter? Investigating scale efficiency of peasant rice farmers in northern Ghana. Econ Bull. 2016;36(4):2275-90

5. Anseeuw W, Jayne TS, Kachule R, Kotsopoulos J. The quiet rise of medium-scale farms in Malawi. Land. 2016;5:3-19.

6. Arnab R. Survey sampling theory and applications. Academic Press; 2017

7. Asante-Addo C, Mockshell J, Siddig K, Zeller M. Agricultural credit provision: what really determines farmers' participation and credit rationing? In: Paper presented at the 5th International Conference of the African 
Association of Agricultural Economists, Addis Ababa, 23-26 September 2016.

8. Asteriou D, Hall SG. Applied econometrics. New York: Palgrave Macmillan; 2011. p. 552 (Us).

9. Adjognon SG, Liverpool-Tasie LSO, Reardon TA. Agricultural input credit in Sub-Saharan Africa: telling myth from facts. Food Policy. 2017;67:93-105.

10. Akudugu MA. Agricultural productivity, credit and farm size nexus in Africa: a case study of Ghana. Agric Financ Rev. 2016;76(2):288-308.

11. Awunyo-Vitor D, Al-Hassan RM, Sarpong DB. Impact of formal financial market participation on farm size and expenditure on variable farm inputs: The case of maize farmers in Ghana. Int Sch Res Not. 2014;2014:1-9.

12. Barrett CB, Bellemare MF, Hou JY. Reconsidering conventional explanations of the inverse productivity-size relationship. World Dev. 2010;38(1):88-97.

13. Burton RJ. An alternative to farmer age as an indicator of life-cycle stage: the case for a farm family age index. J Rural Stud. 2006;22(4):485-92.

14. Chapoto A, Mabiso A, Bonsu A. Agricultural commercialization, land expansion, and homegrown large-scale farmers: insights from Ghana. Intl Food Policy Res Inst. 2013. https://doi.org/10.2139/ssrn.2343154.

15. Giampietri E, Yu X, Trestini S. The role of trust and perceived barriers on farmer's intention to adopt risk management tools. Bio-Based Appl Econ. 2020;9(1):1-24.

16. Cohen L, Manion L, Morison K. Research methods in education. London: Raitledge Flamer; 2000

17. Diao X, Cossar F, Houssou N, Kolavalli S. Mechanization in Ghana: Emerging demand, and the search for alternative supply models. Food Policy. 2014;48:168-81

18. Debonne N, van Vliet J, Ramkat R, Snelder D, Verburg P. Farm scale as a driver of agricultural development in the Kenyan Rift Valley. Agric Syst. 2020;186:102943

19. Collier P. The politics of hunger. Foreign Aff. 2008;87(6):67-79.

20. Donkor E, Owusu V. Effects of land tenure systems on resource-use productivity and efficiency in Ghana's rice industry. Afr J Agric Resour Econ. 2014;9(311-2019-5617):286-99.

21. Eastwood R, Lipton M, Newell A. Farm size. In: Pingali PL, Evenson RE, editors. Handbook of agricultural economics. North Holland: Elsevier; 2010.

22. FAO (2015). Ghana at a glance. FAO. http://www.fao.org/ghana/fao-inghana/ghana-at-a-glance/en/

23. Fan S, Brzeska J, Keyzer M, Halsema A. From subsistence to profit: transforming smallholder farms. Washington, DC: International Food Policy Research Institute; 2013.

24. Garner E, Ana Paula de la O Campos. Identifying the "family farm": an informal discussion of the concepts and definitions. ESA Working Paper No. 14-10. Rome: FAO; 2014. https://ageconsearch.umn.edu/record/ 288978/.

25. Filli FB, Onu JI, Adebayo EF, Tizhe I. Factors influencing credits access among small scale fish farmers in Adamawa State, Nigeria. J Agric Econ Environ Soc Sci. 2015;1 (1):46-55.

26. Ghana Statistical Service (GSS). Ghana living standards survey round 7 (GLSS7): Main report. Accra: Ghana Statistical Service; 2017

27. Graeub B, Chappell MJ, Wittman H, Lederman S, Kerr RB, Gemmill-Herren B. The state of family farms in the world. World Dev. 2016;87:1-15.

28. Grain. Hungry for land: small farmers feed the world with less than a Quarter of All farm land. GRAIN Report; 2014

29. Greene WH. Econometric analysis. 5th ed. New Jersey: Prentice Hall; 2003.

30. Hazell PBR, Poulton C, Wiggins S, Doward A. The Future of small farms for poverty reduction and growth. 2020 discussion paper 42, vol. 42. Washington DC: International Food Policy Research Institute; 2007.

31. Houssou N, Chapoto A. The changing landscape of agriculture in Ghana: drivers of farm mechanization and its impacts on cropland expansion and intensification. IFPRI-Discussion Papers, (1392); 2014.

32. Ironkwe A, Madu T. Gender factors influencing technical efficiency of cassava farmers in Akwa Ibom state, Nigeria. J Sustain Dev. 2017;11(1):59-64.

33. Jayne TS, Chamberlin J, Traub L, Sitko N, Muyanga M, Yeboah FK, Anseeuwe W, Chapoto A, Wineman A, Nkonde C, Kachule R. Africa's changing farm size distribution patterns: the rise of medium-scale farms. Agric Econ. 2016;47:197-214.

34. Jayne TS, Chapoto A, Sitko N, Nkonde C, Muyanga M, Chamberlin J. Is the scramble for land in Africa foreclosing a smallholder agricultural expansion strategy?". J Int Aff. 2014;67(2):35-53.
35. Jayne TS, Mather D, Mghenyi E. Principal challenges confronting smallholder agriculture in Sub-Saharan Africa". World Dev. 2010;38(10):1384-98.

36. Khalil CA, Conforti P, Ergin I, Gennari P. Defining small-scale food producers to monitor target 2.3. Of the 2030 agenda for sustainable development. Food and Agriculture Organization of the United Nations 17, 2017.

37. Khandker SR, Faruqee RR. The impact of farm credit in Pakistan. Agric Econ. 2003;28(3):197-213.

38. Kwapong NA, Ankrah DA, Boateng-Gyambiby D, Asenso-Agyemang J, Fening LO. Assessment of agricultural advisory messages from farmerto-farmer in making a case for scaling up production: a qualitative study. Qual Rep. 2020;25(8):2011-25. https://doi.org/10.46743/2160-3715/2020. 4241.

39. Larson DF, Otsuka K, Matsumoto T, Kilic T. Should African rural development strategies depend on smallholder farms? An exploration of the inverse productivity hypothesis. Policy Research Working Paper. Washington, DC: The World Bank; 2012. https://elibrary.worldbank.org/doi/abs/10. 1596/1813-9450-6190

40. Lowder SK, Skoet J, Raney T. The number, size, and distribution of farms, smallholder farms, and family farms worldwide. World Dev. 2016;87:16-29.

41. Martey E, Al-hassan R, Kuwornu J. Commercialization of smallholder agriculture in Ghana: a tobit regression analysis. Afr J Agric Res. 2012;7(14):2131-41.

42. Masamha B, Thebe V, Uzokwe VN. Mapping cassava food value chains in Tanzania's smallholder farming sector: the implications of intra-household gender dynamics. J Rural Stud. 2018;58:82-92.

43. Masters WA, Djurfeldt AA, De Haan C, Hazell P, Jayne T, Jirström M, Reardon T. Urbanization and farm size in Asia and Africa: Implications for food security and agricultural research. Glob Food Sec. 2013;2(3):156-65.

44. Meng X. Scalable simple random sampling and stratified sampling. In: Proceedings of the international conference on machine learning, 2013. p. 531-539. PMLR. http://proceedings.mlr.press/v28/meng13a.html

45. Mhlanga N. Private sector agribusiness investment in sub-Saharan Africa. Agricultural management, marketing and finance working document 27, Food and Agricultural Organization FAO, Rome, Italy; 2010.

46. Muyanga M, Sitko N, Jayne TS, Hichaambwa M. Medium-scale farmer growth trajectories in Africa: Implications for broad-based growth and poverty reduction. Paper presented at the future agricultures conference on political economy of agricultural policy in Africa, Pretoria, South Africa, March 18-20, 2013.

47. Muyanga M, Jayne TS. Revisiting the farm size-productivity relationship based on a relatively wide range of farm sizes: evidence from Kenya. Am J Agr Econ. 2019;101:1140-63.

48. Nagayets O. Small farms: current status and key trends. The future of small farms 355; 2005. Wye College, June 26-29, 2005

49. Ohene-Yankyera K. Determinants of farm size in land-abundant agrarian communities of northern Ghana. J Sci Technol (Ghana). 2004;24(2):45-53.

50. Peck Christen R, Pearce D, Rubio F, Acevedo JP, Brar A, Ayee G, Reinsch M. Managing risks and designing products for agricultural microfinance: features of an emerging model. The World Bank. 2005. https://agris.fao. org/agris-search/search.do? recordID=us2012416177

51. Rada NE, Fuglie KO. New perspectives on farm size and productivity. Food Policy. 2019;84:147-52.

52. Rapsomanikis G. Small farms big picture: Smallholder agriculture and structural transformation. Development. 2015;58(2):242-55.

53. Ruml A, Qaim M. Effects of marketing contracts and resource-providing contracts in the African small farm sector: insights from oil palm production in Ghana. World Dev. 2020;136:105110.

54. Santeramo F. I learn, You learn, We gain experience in crop insurance markets. Appl Econ Perspect Policy. 2019;41(2):284-304.

55. Santeramo FG, Goodwin BK, Adinolfi F, Capitanio F. Farmer participation, entry and exit decisions in the Italian crop insurance programme. J Agric Econ. 2016;67(3):639-57.

56. Sekyi S, Domanban PB, Honya GK. The impact of informal credit on rural agricultural productivity in the savannah ecological zone of Ghana. Afr J Econ Manag Stud. 2019;11(2):301-15.

57. Tanko M, Iddrisu A, Alidu AF. Determinants of rice yield in Northern region of Ghana, the role of policy. Asian J Agric Ext Econ Sociol. 2016;9(2):1-11. 
58. Taiwo A, Kumi F. Status of agricultural mechanization in Ghana: a case study of maize producing farmers in Ejura/Sekyedumase district, Ashanti region. Int Res J Eng Technol. 2015;2(9):36-43.

59. Tolulope, R. J. and Omonona, B. T. (2018). Determinants of transition in farm size among cassava-based farmers in Nigeria. Kaestart J Soc Sci, 1-7.

60. Udensi UE, Tarawali G, Favour EU, Asumugha GN, Ezedinma C, Okoye BC, Okarter C, llona P, Okechukwu RU, Dixon A. Adoption of selected improved cassava varieties among smallholder farmers in South-Eastern Nigeria. Journal of Food, Agriculture and Environment. 2011;9(1):329-35.

61. Wiggins S, Argwings-kodhek G, Leavy J, Poulton C. Small farm commercialization in Africa: Reviewing the issues. Future Agricultures, Research paper 023; 2011. http://citeseerx.ist.psu.edu/viewdoc/download?doi= 10.1.1.360.7442\&rep=rep1\&type $=$ pdf.

\section{Publisher's Note}

Springer Nature remains neutral with regard to jurisdictional claims in published maps and institutional affiliations.
Ready to submit your research? Choose BMC and benefit from:

- fast, convenient online submission

- thorough peer review by experienced researchers in your field

- rapid publication on acceptance

- support for research data, including large and complex data types

- gold Open Access which fosters wider collaboration and increased citations

- maximum visibility for your research: over $100 \mathrm{M}$ website views per year

At BMC, research is always in progress.

Learn more biomedcentral.com/submissions 